\title{
A INFORMAÇÃO ARTÍSTICA
}

\section{Ana Claudia Inacio da Silva Pirolo ${ }^{1}$}

\begin{abstract}
RESUMO
Estudo da arte sob a ótica da Ciência da Informação com o objetivo de identificar a função da informação na formação do público para arte e sua contribuição na democratização da arte. Para isso empreendeu-se uma pesquisa bibliográfica com o objetivo de analisar a associação da Arte e da Ciência da Informação. Realizou-se um estudo empírico sobre o comportamento do público em relação a usabilidade da informação sobre a arte para interpretar a obra estética. Com isso expande-se a compreensão das condições de recepção da obra estética quando mediada pela informação.
\end{abstract}

\section{PALAVRAS-CHAVES}

Informação; Arte; Mediação; Sistemas de informação; Formação de público; Consumo

\section{ARTISTIC INFORMATION}

\begin{abstract}
Study of art from the perspective of information science in order to identify the role of information in the formation of public art and its contribution to the democratization of art. To do so, undertook a literature search in order to analyze the association of Art and Information Science. We conducted an empirical study on the behavior of the public regarding the usability of information about art to interpret the aesthetic work. With that expands the understanding of the conditions of reception aesthetics of the work when mediated by information.
\end{abstract}

\section{KEYWORDS}

Information; Art, Mediation; Information systems; Training for public consumption

\footnotetext{
${ }^{1}$ Mestre em Ciência da Informação PUC-Campinas - 2007. Coordenadora e Docente do Curso de Comunicação Social - Publicidade e Propaganda da Faculdade Anhanguera de Jacareí SP. Mantenedora da Galeria de Arte ANA PIROLO (www.webgaleria.com.br). E-mail: anapirolo@webgaleria.com.br / ana.pirolo@ unianhanguera.edu.br.
} 


\section{INTRODUÇÃO}

O desenvolvimento acelerado das tecnologias de informática e telecomunicações, o surgimento de novas mídias para o armazenamento de dados, sua disseminação, recuperação e o surgimento da Sociedade do Conhecimento, também denominada Sociedade da Informação, buscam colocar à disposição da população conteúdos de informação das mais variadas naturezas. E a arte que sempre foi, pretensiosamente, um assunto de domínio da elite, pode tornar-se uma informação de fácil acesso, desde que seja trabalhada de maneira eficiente e abrangente, levando em consideração as necessidades de seu público. Por isso, o conteúdo artístico também faz parte dessa mudança.

Foi-se tempo em que coleções, acervos e reservas técnicas eram inacessíveis ao público, atendendo somente às necessidades de um segmento determinado da sociedade.

Com o surgimento destes novos cenários, como o advento da globalização, as novas tecnologias que favorecem a distribuição e a recuperação da informação, torna-se quase impossível manter a arte como objeto exclusivo de uma única classe social. A cultura moderna, que exalta a autonomia da arte, as práticas de mercado e da comunicação massiva buscam a sua democratização, chegando a todos os segmentos da sociedade. Essa mesma cultura busca construir e aprimorar espaços nos quais o saber e a criação possam desenvolver-se com autonomia.

Estudar a Ciência da Informação, uma ciência interdisciplinar, sob o aspecto artístico torna-se essencial quando buscamos entender qual é a contribuição da informação na democratização da arte facilitando o acesso de seu público, através de uma mediação coerente, responsável e ainda compreender como estes sistemas de informação atuam nos novos cenários da arte e da Ciência da Informação.

Como objetivos específicos temos:

1. Entendimento da arte como uma manifestação básica do ser humano. 
2. Análise do público para arte, seu comportamento diante da informação artístico-cultural, através de um estudo empírico, enfatizando a importância da mediação e motivação.

3. A função da informação na formação de público para a arte, mediante análise do uso do produto de informação artística através da pesquisa empírica "antes-depois" em uma amostra aleatória simples.

\section{O QUE SE ENTENDE POR ARTE}

Olhando em volta, as pessoas veem-se rodeadas de manifestações artísticas. A arte é o registro de diversos períodos da História da Humanidade, traduzindo um conteúdo abrangente da criação humana com valores estéticos (beleza, equilíbrio, harmonia, revolta) que sintetizam as suas emoções, sua história, seus sentimentos e a sua cultura.

Esses registros vêm desde a Pré-História, época em que o homem passou a conviver em sociedade, criando formas de se expressar. A arte foi, sem dúvida, o primeiro desses registros, surgindo antes da linguagem falada e da escrita, através da criação de utensílios e das pinturas nas cavernas, também chamadas de pinturas rupestres. O registro da arte antecede todas as demais.

Como bem observa Baumgart (1999, p.23) "o primeiro legado da humanidade é a arte pinturas e esculturas - depois das ferramentas mais simples, antes que houvesse a arquitetura, a música, a literatura e com elas, inicia-se a História da Arte”.

O homem criou objetos para satisfazer suas necessidades práticas. Ferramentas para cavar a terra, utensílios de cozinha, outros objetos foram criados por serem interessantes ou possuírem um caráter instrutivo. Assim o homem cria a arte como meio de vida, para que o mundo saiba o que pensa, para divulgar as suas crenças, para estimular e distrair a si mesmo e aos outros, para explorar novas formas de olhar e interpretar objetos e cenas, o seu dia-a-dia.

A arte é uma representação simbólica de um evento e o homem primitivo supõe que possa assegurar a ocorrência presente de tal evento. O desejo de progênie, da morte de um inimigo, de 
sobrevivência depois da morte, ou do exorcismo ou aproximação de espírito mau, constitui motivo para a criação de um símbolo adequado.

Em relação aos símbolos, Araripe (2004, p.111) afirma que "os homens precisam de signos, de imagens, de gestos, dentre outros aspectos carregados de sentido, através dos quais possam se comunicar e ainda se reconhecerem a si próprios no caminhar como seres sociais e, por conseguinte, como seres eminentemente simbólicos".

Através desse breve relato, observa-se a importância da arte para a vida dos seres humanos, apresentando-se como uma necessidade social básica, através da qual o homem procura comunicar sua existência e sentimentos, necessidade que surge no comportamento quando as necessidades mais baixas (fisiológica e segurança) encontram-se relativamente satisfeitas.

\section{A ARTE E A CIÊNCIA DA INFORMAÇÃO}

Este estudo tem como objetivo estudar a contribuição da informação na socialização dos conceitos artísticos, como uma das formas de acesso cultural no contexto da Ciência da Informação. E o grande problema encontrado na relação da arte com a Ciência da Informação é descrever como o acesso à informação pode alterar a compreensão da arte.

Popper (apud SERACEVIC, 1995, p.36) afirma que "não somos estudiosos de um assunto, mas estudiosos de problemas. E problemas devem atravessar os limites de qualquer assunto ou disciplina". Nesse sentido, a ciência da informação, como observa Seracevic (1995), como qualquer outro campo, é também definida por problemas a que se propõe e pelos métodos que escolhe para resolvê-los. Podemos observar que a arte também pode ser entendida como um problema a ser resolvido pela ciência da informação, desde que se associe a informação artística à geração de conhecimento.

Temos ainda, que o autor comenta que a Ciência da Informação possui três características gerais, que são sua razão de existência:

1) É interdisciplinar por natureza 
2) É inexoravelmente conectada à tecnologia da informação

3) É participante ativo, juntamente com outros campos, na evolução da sociedade da informação.

A interdisciplinaridade, de fato, não se constitui em reunião de conhecimento, produzido por diferentes campos: "A interdisciplinaridade traduz-se por uma colaboração entre diversas disciplinas, que leva as interações, isto é, certa reciprocidade nas trocas, de modo que haja, em suma, enriquecimento mútuo. (LE COADIC, 2004, p.20)"

Le Coadic (2004) afirma que a tecnologia da informação, por sua vez, tem por objeto a concepção de produtos, sistemas e serviços que permitem a construção, comunicação, armazenamento e uso da informação.

O mesmo autor observa que a Ciência da Informação é uma ciência social e tem por objeto o estudo das propriedades gerais da informação (natureza, gênese, efeitos) e a análise de seus processos de construção, comunicação e uso.

A arte participa como objeto de estudo da Ciência da Informação a partir da análise de sua gênese, sua natureza e dos efeitos que atingem o público em suas instituições para:

1) Analisar os processos de produção, comunicação e uso dessas informações artísticas.

2) Conceber os sistemas (as coleções compostas de objetos, as exposições feitas com tais objetos, bem como seu exame e manipulação) que permitem sua comunicação, uso e armazenamento.

Seracevic (1995) comenta que o ímpeto do desenvolvimento da Ciência da Informação teve seu início a partir de um artigo escrito há mais de 50 anos por Vannevar Bush (Bush, 1945). Neste artigo histórico, Bush definia de forma sucinta o problema da "explosão da informação", e conseqüentemente, a necessidade de se tornar acessível um gigantesco estoque de conhecimento 
para tanto recorreu-se à tecnologia da informação como um dos instrumentos para enfrentar o problema.

A "explosão da informação" é um problema social, que teve seu início com o desenvolvimento das ciências, com a multiplicação dos registros e dos documentos e hoje se estende a todas as atividades humanas, inclusive à arte, como veremos neste estudo.

De acordo com Canclini (2006), um dos fatores dessa "explosão" em relação à informação artística, deu-se pelo fato do predomínio da cultura escrita sobre a visual nos países que chegaram primeiro a uma discreta taxa de alfabetização e onde a formação da modernidade esteve nas mãos de elites que superestimaram a escrita.

O autor ainda afirma que em países como a Argentina, Brasil, Chile e Uruguai, a documentação inicial das tradições culturais foi realizada mais por escritores - narradores e ensaístas - que por pesquisadores da cultura visual.

Portanto, fica claro o porquê dessa grande distância que o público tem em relação às obras estéticas visuais. Mesmo havendo registros visuais desde a pré-história, o homem ainda vivencia a falta de uma "alfabetização" da imagem. E em sociedades com alto índice de analfabetismo, documentar e organizar a cultura privilegiando os meios escritos é uma maneira de reservar para a minoria a memória e o uso dos bens simbólicos, proporcionando um modo mais intelectualizado de circulação e apropriação dos bens culturais, alheio às classes subalternas, habituadas à elaboração e comunicação visual de suas experiências. Mesmo as classes subalternas, habituadas à comunicação visual, são totalmente analfabetas no sentido de analisar a obra estética.

Como bem observa Canclini (2006, p.146) "ser culto implica reprimir a dimensão visual em nossa relação perceptiva com o mundo e inscrever sua elaboração simbólica em um registro escrito".

O autor completa que temos na América Latina mais histórias da literatura que das artes visuais e musicais; e, é claro, mais sobre a literatura das elites que sobre as manifestações equivalentes das camadas populares. 
Com o objetivo de resgatar a cultura visual, justificam-se os esforços e os investimentos no desenvolvimento de modernos sistemas de recuperação da informação artística em museus e centros culturais. Este é o início da relação da arte estudada sob a luz da Ciência da Informação. Seracevic (1995) define a Ciência da Informação como um campo voltado à pesquisa científica e à prática profissional e que trata dos problemas da comunicação dos conhecimentos e dos registros de conhecimentos na sociedade, no contexto de usos e necessidades das informações sociais, institucionais e/ou individuais.

\section{A ARTE COMO INFORMAÇÃO}

A arte como uma representação simbólica de um momento, de uma referência, de um contexto, procura transparecer um ideal, uma idéia, um conteúdo, uma informação, para quem a observa. Uma obra de arte pode ser apreciada e compreendida, ser considerada um instrumento para desencadear uma possível informação em um observador. Torna-se necessário refletir sobre o significado do termo informação no contexto da arte. Sendo a arte um processo de transferência da criação humana, como já foi comentado e, por sintetizar as emoções, a história, sentimentos e a cultura do homem, esse conceito pode ser considerado o conteúdo informacional da obra estética.

Quando se refere à obra estética, o termo conteúdo informacional está intimamente relacionado não à forma da obra física, e, sim à sua função, isto é, ao seu significado. E é justamente este tipo de informação que buscamos analisar através da Ciência da Informação.

Robredo (2003) apresenta algumas características do termo informação que nos interessam para este estudo, tais como: "a informação é suscetível de ser registrada (codificada) de diversas formas, duplicada e reproduzida; transmitida por diversos meios; medida e quantificada; adicionada a outras informações; organizada, processada e reorganizada segundo critérios e; recuperada quando necessário".

De acordo com Oliveira (2005), “informação é algo invisível (não concreto), desencadeada por um meio concreto. O suporte físico, com seu código, pode desencadear algo no receptor, mas não pode determinar o seu efeito, porque este efeito dependerá da estrutura do receptor”. 
Para Le Coadic (2004, p.4) "a informação é um conhecimento inscrito (registrado) em forma escrita (impressa ou digital), oral ou audiovisual, em um suporte". A informação comporta um elemento de sentido. É um significado transmitido a um ser consciente por meio de uma mensagem inscrita em um suporte.

Ao relacionar os conceitos e características da arte e da informação, pode-se concluir que a arte, por ser a transferência do conteúdo da criação humana, é suscetível de ser registrada (codificada) de diversas formas, duplicada e reproduzida; transmitida por diversos meios; medida e quantificada; organizada, processada e reorganizada segundo critérios e, recuperada, quando necessário, sendo um mecanismo de transferência de conhecimento. E esse conhecimento é produzido pelo homem. Portanto, de acordo com Canclini (1984), a arte é produção, porque consiste numa apropriação e numa transformação da realidade material e cultural, mediante um trabalho de satisfazer uma necessidade social, de acordo com a ordem vigente em cada sociedade.

Ao pensar desse modo, cria-se uma relação entre o processo artístico e a interpretação do homem, e conclui-se que uma obra de arte não chega a sê-lo, caso não seja recebida, isto é, se o receptor não perceber a obra de arte como informação que reflete o conhecimento de um período, de um povo, de um sentimento, e que captada como informação, pode gerar igualmente conhecimento.

Completando, Tálamo (2004) afirma que o conhecimento, ou mais exatamente sua produção requer três elementos para se concretizar: o sujeito, a linguagem e o objeto a ser conhecido. "Não se pode conceber um processo de conhecimento na ausência do sujeito. Quem conhece, por sua vez, conhece sempre algo. E para isso é fundamental a ação da linguagem, isto é, do sistema simbólico". O homem ainda vivencia a falta de uma "alfabetização" da imagem, o que gera certos obstáculos da compreensão da obra estética através do contexto da informação, como está apresentado no quadro abaixo: 
QUADRO 1

Compreensão da obra estética através do sujeito e sua linguagem

\begin{tabular}{|c|c|c|c|}
\hline $\begin{array}{c}\text { A OBRA } \\
\text { ESTÉTICA }\end{array}$ & SUJEITO & LINGUAGEM & $\begin{array}{c}\text { OBJETO A SER } \\
\text { CONHECIDO }\end{array}$ \\
\hline $\begin{array}{c}\text { A arte como objeto } \\
\text { tangível }\end{array}$ & Forma & $\begin{array}{l}\text { O que a obra física } \\
\text { representa em } \\
\text { relação à técnica } \\
\text { empregada, cores e } \\
\text { imagem. }\end{array}$ & A obra em si \\
\hline $\begin{array}{c}\text { A arte como objeto } \\
\text { intangível } \\
\text { (informação) }\end{array}$ & Função & $\begin{array}{c}\text { O que a obra } \\
\text { realmente representa } \\
\text { em relação à } \\
\text { informação, ao } \\
\text { significado que } \\
\text { expressa. }\end{array}$ & $\begin{array}{l}\text { A informação } \\
\text { artística }\end{array}$ \\
\hline
\end{tabular}

A análise da obra estética pode ser determinada por dois segmentos: a arte como objeto tangível, isto é, o público observa a obra física, suas cores, técnica empregada, pode até mesmo ter informações sobre seu artista e ainda a arte como objeto intangível: a informação artística é mais abrangente do que a o objeto físico, isto é, a obra oferece ao observador muito mais informação, significado, do que a obra física.

Em relação especificamente à obra estética visual que esteja, por exemplo, exposta em uma mostra, exposição, catálogo ou livro de arte, o vínculo integrador da mesma com o público é, com certeza, a informação contida na obra. Porém, torna-se bastante curioso o estudo de como o público recebe e administra esse tipo de informação. 
Canclini (1984) comenta que a arte como toda linguagem que quer ser comunicada, deve ater-se a códigos produzidos e manejados socialmente. E, como comprova Bosi (1985, p.53): “existem alguns aspectos importantes da obra de arte: a objectualidade, por exemplo. Um quadro é um ser material e tem como efeito psicológico ser uma obra percebida, sentida e apreciada por seu receptor".

Em estudos da Ciência da Informação, o papel do receptor é fundamental quando se fala em informação no campo da arte, a noção de imagem vincula-se essencialmente à representação visual, seja através de afrescos, pinturas, iluminuras, ilustrações decorativas, desenhos, gravuras, filmes, vídeos, fotografias e até imagens de síntese.

\section{Cognição e Informação}

Neste estudo analisa-se que o vínculo integrador entre sujeito (público para a arte) e o objeto a ser consumido (a obra estética em si) tem como linguagem a representação simbólica da obra, sua função.

Essa obra, representada por uma imagem, procura transportar algo ao seu observador, porém este "algo" só poderá desencadear informação em alguém que tenha a estrutura mental, social e cultural para lhe dar sentido. Isso significa que alguns requisitos são necessários ao observador que não tem conhecimento dos períodos e estilos artísticos torna-se difícil analisar as obras das diversas fases de Picasso, por exemplo.

Uma obra pode ser apreciada ou pode ser desprezada pelo mesmo observador que não tenha conhecimento de seu período histórico sobre o artista ou não tenha conhecimento da técnica empregada.

Como comprova Kobashi e Tálamo (2003), não se pode dissociar a informação do campo da cultura, já que a informação é um elemento fundamental do processo de se conhecer o mundo.

Diante dos conceitos acima discutidos, chega-se a algumas conclusões: 
1. A informação exige compreensão e mediação eficientes para a passagem da mensagem, mesmo quando nos referimos à mensagem artística, e esta mediação provém do ser humano.

2. A informação exige a presença do ser humano e o conhecimento adquirido pela informação é construído individualmente.

3. A informação necessita chegar a um público e ser de fato recebida e compreendida, gerando conhecimento, ações.

4. O público, ou seja, o receptor é quem deverá reconhecer a informação e transformar a informação artística em conhecimento, utilizando-se de uma informação produtora de valor - bem social.

A fórmula de Bertram C. Brookes ( apud Silva, 2003), exprime claramente a passagem de um estado de conhecimento $\mathrm{K}(\mathrm{S})$ para novo estado de conhecimento $\mathrm{K}(\mathrm{S}+\delta S)$ através de um acréscimo de conhecimento $\delta \mathrm{K}$ extraído de um incremento de informação $\delta \mathrm{I}$, indicando $\delta \mathrm{S}$ o efeito dessa modificação no estado inicial de conhecimento.

$$
\begin{aligned}
& \mathrm{K}(\mathrm{S})+\delta \mathrm{K}=\mathrm{K}(\mathrm{S}+\delta \mathrm{S}) \\
& \text { Sendo que: } \\
& \mathrm{K}=\text { conhecimento } \\
& \mathrm{S}=\text { estado anterior de conhecimento } \\
& \delta \mathrm{K}=\text { conhecimento acrescido } \\
& \delta \mathrm{I}=\text { incremento da informação }
\end{aligned}
$$


Em outras palavras, torna-se óbvio que a apreciação de uma obra estética, seja ela, pintura, escultura, música, arquitetura, permite que o seu observador (público) possa ter um conhecimento acrescido através da análise minuciosa da mesma, esta informação será comparada com os diversos estados de conhecimento já adquiridos anteriormente pelo observador, proporcionando um novo conhecimento, ou seja, um conhecimento que se soma à capacidade humana (interna) de conhecer, enriquecendo-a, quanto mais conhecimento se tem, mais informações se produzem.

Silva (2003) observa ainda que a cognição seja uma "sobreestrutura" abordável através de alguns tópicos básicos e essenciais: a percepção, a memória, modelos conexionistas, representação mental, a imagem mental, a resolução de problemas, o raciocínio, o raciocínio dedutivo, o indutivo, a cognição social e o desenvolvimento cognitivo.

\begin{abstract}
As representações mentais podem ser classificadas em representações analógicas, baseadas na percepção, e representações proposicionais, baseadas no significado. Exemplo de uma representação analógica é uma imagem mental. As representações proposicionais são abstratas, semelhantes à linguagem, com a qual, todavia não se deve confundir. A representação proposicional refere-se ao conteúdo abstrato, aos conceitos subjacentes a uma situação (ANDERSON apud JESUÍNO, 2001. p.324-325).
\end{abstract}

Uma obra estética, vista por alguém que desconheça sua técnica, sua representatividade provoca um aumento de saber/ de conhecimento/ de informação, mas não basta para que interfira diretamente na dimensão cognitiva. Para tanto e para que haja uma assimilação geradora de novos conteúdos/ de novas obras sobre a mesma temática, é preciso que o sujeito reúna várias condições endógenas e exógenas facilitadoras dessa dinâmica, como bem observa SILVA (2003). Estabelecese, assim, como demonstra o autor, uma diferenciação orgânico-funcional entre os "produtos" da cognição humana - os textos, as imagens, os desenhos, isto é, o conhecimento ou a informação manifesta - e os processos cognitivos (os processos de cognição) propriamente ditos.

Santaella e Nöth (2001) já comentavam que o mundo das imagens se divide em dois domínios:

1. Domínio das imagens como representações visuais: desenhos, pinturas, gravuras, fotografia e as imagens cinematográficas. Imagens, nesse sentido, são objetos materiais, signos que representam o nosso meio ambiente visual. 
2. Domínio imaterial das imagens na nossa mente. Neste domínio, imagens aparecem como visões, fantasias, imaginações, esquemas, modelos ou, em geral, como representações mentais.

Ambos os domínios da imagem não existem separados, pois estão ligados. Não há imagens como representações visuais que não tenham surgido de imagens na mente daqueles que a produziram, do mesmo modo que não há imagens mentais que não tenham alguma origem no mundo concreto dos objetos visuais.

O produtor de uma obra estética visual, uma pintura, por exemplo, pode buscar a referência de uma imagem em sua mente, uma representação mental, sua cognição, expressando-a através de pinceladas e cores e até mesmo por uma técnica específica utilizada para a execução da obra, ou mesmo buscar como referência um objeto concreto. Porém, em ambos os exemplos, o estilo do autor predomina em sua obra, distinguindo-a de outras obras e artistas ou, ainda, caracterizando-a através de um período artístico.

O mesmo pode-se dizer de quem observa a obra estética, esse busca referências da imagem em seu estoque de informação mental ou, ainda, pode relacionar a imagem da obra com um objeto concreto, pertencente ao seu dia-a-dia.

A ciência cognitiva estudou, até o momento, principalmente a representação mental da informação lingüística e visual. E de que forma esse conhecimento é armazenado? Será que a informação visual (só) aparece na forma de imagens mentais? O que dizer das obras abstratas? Como sua informação pode ser processada na mente do público, se essas obras não pertencem ao domínio das imagens mentais e nem ao domínio das imagens concretas? De que forma o conhecimento visual é representado?

Conforme Santaella e Nöth (2001) quando se leva em conta a relação da imagem com o referente, isto é, com o(s) objeto(s) que a imagem representa, há três grupos fundamentais de imagem: as não representativas, as figurativas e as simbólicas. 
As não-representativas, comumente chamadas de abstratas, reduzem a declaração visual a elementos puros como: os tons, as cores, manchas, brilhos, contornos, movimentos, ritmos, etc, enfim, são formas que não representam, a priori, nada que está fora delas.

As imagens figurativas são aquelas que transpõem para o plano bidimensional ou criam no espaço tridimensional réplicas de objetos pré existentes e, no mais das vezes, visíveis no mundo externo, quer dizer, apontam, com maior ou menor ambigüidade, para objetos ou situações reconhecíveis.

As simbólicas são imagens que, mesmo sendo figurativas, representam algo de caráter abstrato e geral.

$\mathrm{Na}$ imagem figurativa, como o próprio nome diz, a relação referencial é explícita, quer dizer, trata-se de imagens que sugerem, indicam, designam objetos ou situações existentes. $\mathrm{O}$ autor de uma obra estética figurativa acaba, inevitavelmente, trazendo para o observador da obra a historicidade que pertence ao objeto que a imagem representa. É nesse sentido que imagens figurativas podem funcionar como documento de época.

Ao contrário, as imagens abstratas não podem funcionar como indicadores de tempo. São imagens atemporais, que só são habitadas de tempo pela medição do tempo perceptivo do observador.

Já as imagens simbólicas, embora possam sugerir a temporalidade de possíveis objetos, essa temporalidade é sempre geral e vaga, genérica e universalizante.

A percepção nasce do cruzamento entre o observador da obra estética e um objeto percebido. Perceber não é fenômeno instantâneo, pois o processamento da informação, que está envolvido em todo ato perceptivo, desenvolve-se no tempo. É certo que alguns estágios da percepção são tão rápidos a ponto de criarem a ilusão de que ocorrem fora do tempo. Contudo, mesmo que aparentemente imperceptível, há sempre uma duração envolvida na recepção e processamento de estímulos pelos órgãos sensórios e pelo cérebro. 
Curioso, por exemplo, é detectar o modo como exploramos uma imagem, o que é feito não de modo global, mas por fixações sucessivas que duram alguns décimos de segundo cada uma e limitam-se, estritamente, às partes da imagem mais providas de informação.

\section{PESQUISA EMPÍRICA}

Em quase todos os itens a arte foi discutida sob a ótica da Ciência da Informação, principalmente com as bases da pesquisa bibliográfica, sem a confirmação efetiva de todas as conclusões através de uma pesquisa empírica.

Facilitar o acesso à informação pode mesmo formar um público para a arte mais consciente e crítico, satisfazendo sua necessidade por informação? Em contrapartida: por que mesmo com o acesso facilitado não se usufrui da informação?

Com o intuito de entender esta relação foi desenvolvida uma pesquisa empírica, de modalidade "antes-depois", com dois grupos - o experimental e o de controle.

Neste caso, o grupo experimental e o de controle são medidos no início e no fim do período experimental. O estímulo, que até mesmo podemos classificar de motivação ou mediação, foi introduzido apenas no grupo experimental.

Como o grupo de controle e o experimental são submetidos à mensuração inicial e as influências, a diferença entre os resultados dos dois grupos constitui medida de influência do estímulo/ motivação produzido. Para alguns autores, apenas as pesquisas deste grupo podem ser consideradas rigidamente experimentais.

Lakatos e Marconi (2002) afirmam que quando se deseja colher informações sobre um ou mais aspectos de um grupo grande ou numeroso, verifica-se, muitas vezes, ser praticamente impossível fazer um levantamento do todo. Daí a necessidade de investigar apenas uma parte dessa população ou universo, também chamada de amostra. 
Conceituando amostra, é uma porção ou parcela, concevientemente selecionada do universo (população).

Para Yule e Kendall (apud Lakatos e Marconi, 2002, pág.42) "a escolha de um indivíduo, entre uma população, é o acaso (aleatória), quando cada membro da população tem a mesma probabilidade de ser escolhido".

Nesta pesquisa, para que a seleção dos pesquisados fosse feita ao acaso, foi realizado o sorteio utilizando-se o número da lista de chamada.

Strickland (2003, p. 1) afirma que assim como a música, a arte é uma linguagem universal. "Ver uma obra de arte é sempre uma experiência agradável, mas apreciá-la integralmente exige certo conhecimento".

A informação serve como uma das formas de acesso para a compreensão dessas manifestações artísticas, através do tratamento informacional da obra estética e de mediação/motivação pelos sistemas de informação. Como o público recebe e administra este tipo de informação é o que a pesquisa experimental buscará solucionar.

Público que têm acesso à informação sobre a arte, seja ela qual for, motivada pela mediação tem mais possibilidade de análise das manifestações artísticas, principalmente as empregadas em artes visuais, ao contrário do público sem algum tipo de acesso e mediação.

Foi desenvolvida uma pesquisa científica aplicada, direcionada a um público de nível escolar superior incompleto, pertencente a diversas profissões, com a finalidade de:

1- Analisar o comportamento das pessoas que não tiveram acesso às informações complementares da obra (motivação e mediação);

2- Analisar o comportamento das pessoas que efetivamente tiveram acesso à informação complementar para a análise da obra (motivação e mediação);

3- De que forma essas informações, ou a falta delas, foram utilizadas. 
A pesquisa empregada foi a empírica, pois através desta foi possível detectar um objeto de estudo, neste caso a informação sobre arte, selecionar as variáveis capazes de influenciá-la (pessoas com acesso à informação facilitado e pessoas sem acesso algum à informação), definindo as formas de controle e de observação dos efeitos que a variável produz no objeto, onde o pesquisador é um agente ativo.

Foi selecionada uma amostra aleatória de 121 pessoas, também chamada de Grupo A, pertencentes aos cursos de administração e publicidade e propaganda, do período noturno da Faculdade Anhanguera, de Jacareí, ambos os sexos, faixa etária entre 18 e 40 anos, com profissões variadas.

Com o intuito de facilitar a compreensão dos dados e averiguar as possíveis variáveis dependentes, do grupo total (A) originaram-se dois subgrupos (B e C), que serão analisados em seguida, de forma segmentada.

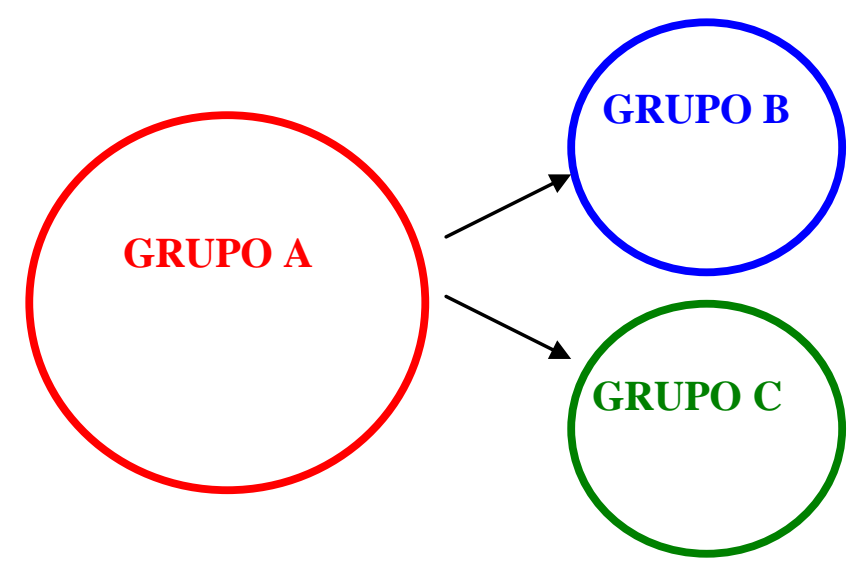

FIGURA 1 - Os grupos e subgrupos analisados nesta pesquisa de campo.

A obra empregada para essa pesquisa foi a do artista Théodore Géricault, denominada "A Jangada da Medusa", datada de 1818-19, obra esta que pertence ao do acervo Museu Louvre em Paris. 


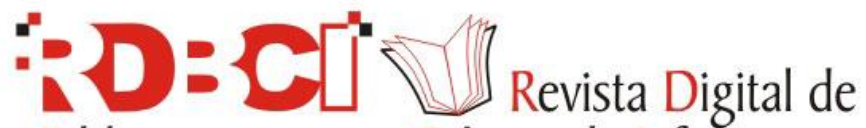 Biblioteconomia e Ciência da Informação}

ARTIGO

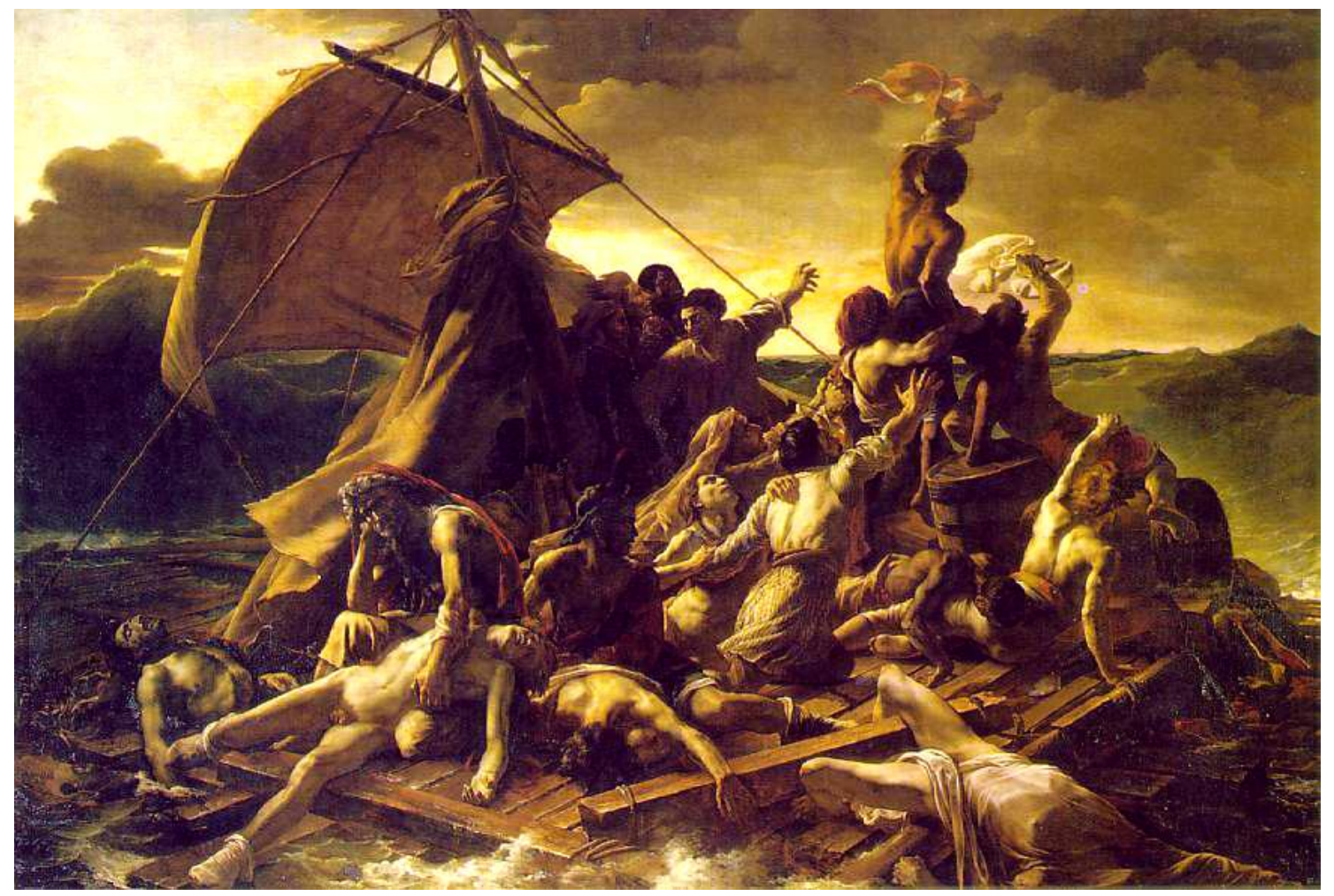

FIGURA 2 - “ A Jangada da Medusa” - Théodore Géricault, 1818-19. Louvre. Paris FONTE - Carol Strickland, p.01

O procedimento utilizado de início foi entregar para todos os entrevistados somente a folha com a imagem da obra. Após 10 minutos de análise, foi distribuída uma segunda folha a um subgrupo, denominado Grupo $C$, dos respondentes selecionados aleatoriamente, contendo uma análise técnica e comentários da historiadora Carol Strickland sobre a obra (mediação). Nesta segunda folha foram apresentados dados tais como:

- Composição

- Movimento

- Unidade e equilíbrio

- Cor e contraste

- Clima

Em posse da segunda folha, foi dada a oportunidade aos pesquisados que a receberam de alterar ou não a análise inicial, após a leitura da mesma. 


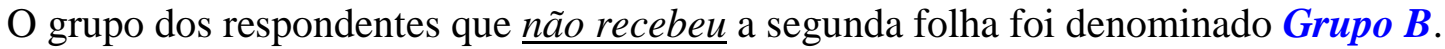

O estudo foi realizado no período de 13 a 17 de março de 2006, durante o horário de aula: das 19h00 às 22h30, nas dependências da Faculdade Anhanguera, em Jacareí.

O questionário foi elaborado de forma a conter apenas uma única atividade: "analise a seguinte obra" e a imagem da obra, nada mais.

A segunda folha direcionada ao subgrupo sorteado apresentava o texto de Carol Strickland, comentando a técnica empregada na obra.

A atividade foi subdividida em três segmentos:

$1^{\circ}$ Parte: Perfil do entrevistado, com as variáveis dependentes.

$2^{\circ}$ Parte: Se o respondente recebeu a segunda folha ou não

$3^{\circ}$ Parte: Interpretação da obra

\section{Descrição dos Resultados}

\section{Grupo A}

Participou da atividade um total de 121 pesquisados (Grupo A), sendo que:

- $\quad 70 \%$ dos participantes da atividade $\underline{\text { não }}$ receberam a segunda folha com a análise técnica da obra (Grupo B);

- $\quad 30 \%$ receberam a segunda folha para auxiliar na análise (Grupo C). 
TABELA 1

Percentual de participantes da atividade

\begin{tabular}{|c|c|c|c|}
\hline Grupo & $\begin{array}{l}\text { Número de } \\
\text { respondentes }\end{array}$ & Característica & $\%$ \\
\hline Grupo A & 121 & $\begin{array}{l}\text { Todos receberam a } \\
\text { folha com a imagem } \\
\text { da obra de Géricault }\end{array}$ & 100 \\
\hline Grupo B & 85 & $\begin{array}{c}\text { Não receberam a } \\
\text { segunda folha com a } \\
\text { análise técnica da } \\
\text { obra de Géricault }\end{array}$ & 70 \\
\hline Grupo C & 36 & $\begin{array}{c}\text { Receberam a segunda } \\
\text { folha com a análise } \\
\text { técnica da obra de } \\
\text { Géricault }\end{array}$ & 30 \\
\hline
\end{tabular}

\section{Análise percentual dos entrevistados que participaram da atividade e não receberam a segunda folha - Grupo B}

Dos $70 \%$ que não receberam a segunda folha, foram identificados três tipos de respostas comuns aos respondentes:

1) Respostas que sugeriram novas interpretações para a obra;

2) Respostas que apenas descreveram a obra e;

3) Respostas que analisaram a obra com referências cognitivas.

Cujas percentagens são:

- $44 \%$ dos respondentes sugeriram novas interpretações para a obra;

- $38 \%$ apenas descreveram a obra; 
- $16 \%$ tiveram como referência para a análise os sentimentos cognitivos, chegando até mesmo a identificar a dualidade esperança/ desespero também comentado por Strickland.

TABELA 2

Percentual de análise da obra pelos participantes do Grupo B

\begin{tabular}{c|c|c}
\hline Número de respondentes & Característica & $\%$ \\
\hline 37 & $\begin{array}{c}\text { Sugeriram novas } \\
\text { interpretações } \\
\text { para a obra }\end{array}$ & 44 \\
\hline 32 & $\begin{array}{c}\text { Os respondentes } \\
\text { apenas }\end{array}$ & 38 \\
& $\begin{array}{c}\text { descreveram a } \\
\text { obra }\end{array}$ & \\
\hline 16 & $\begin{array}{c}\text { Análise baseada } \\
\text { em sentimentos }\end{array}$ & 18 \\
& cognitivos & \\
\hline
\end{tabular}

Foi constatado um fator em comum para os dois grupos de respondentes (B e C). Mesmo não tendo um conhecimento amplo da obra, os respondentes dos dois grupos buscaram em suas estruturas mentais, sociais e culturais um sentido para as suas respostas, isto é, a informação que consta na obra de Géricault será comparada com os diversos estados de conhecimento já adquiridos anteriormente pelos observadores, proporcionando um respaldo às respostas, porém de formas diferentes.

Em relação ao subgrupo de $\mathbf{B}$, que sugeriu novas interpretações, foi observada através da análise de suas respostas a utilização de conceitos imaginários para facilitar a execução da atividade, já que este grupo não dispunha de outro tipo de informação para servir de parâmetro de análise a não ser o de sua própria imaginação.

Como já foi comentada neste estudo, a obra é representada por uma imagem e procura transportar algo ao seu observador, porém este "algo" só poderá desencadear informação em 
alguém que tenha estrutura para lhe dar sentido, fato não identificado neste grupo. Na busca de solucionar o problema imposto pela atividade, a imaginação foi a solução mais fácil de ser apresentada, como descrevem os exemplos abaixo:

"Conta a lenda que as pessoas que olhavam para a Medusa se transformavam em pedra. $\mathrm{Na}$ obra o artista mostra pessoas em forma de pedra. O artista consegue com isto nos dar a idéia de que as pessoas em fuga foram atraídas para o olhar da Medusa e se transformaram em um amontoado de esculturas quebradas."

"A obra nos mostra vários homens mortos após verem o rosto da Medusa"

"Na jangada aparenta ter uma grande confusão entre os tripulantes. Devido ao fato da possível presença da Medusa, que se trata de um personagem da mitologia."

"Um grupo de pessoas adorando o seu deus, que é um homem comum, de carne e osso. Todos eles em busca de alguma coisa acreditando que o seu deus poderá dar. Acredito que sejam pessoas em busca de perdão pelos seus pecados."

"A meu ver o autor quis retratar que existia uma jangada simples, trilhando os mares por um caminho qualquer, mas sofreram um inesperado ataque do monstro grego chamado Medusa. Na real, o autor deve fazer alguma crítica social, algo simbólico, por exemplo, a Medusa deve ser algo ruim, tipo guerra, fome que traz sofrimento a certo grupo de pessoas."

“A jangada está saindo do Louvre à Paris e isto aconteceu no ano de 1818 a 1819 . Onde parece que no barco tem vários tripulantes mortos, doentes e querem chegar logo à Paris por estarem muito tempo viajando no mar.".

"Um grupo de pessoas esperando a salvação divina no meio de uma catástrofe ou algum tipo de peste que os matariam em poucos minutos como os que já estão mortos.”

"Devem estar atrás de terras novas, porque tem uma pessoa em cima de todos olhando o horizonte e tem um apontando para frente." 
Em relação ao grupo que apenas descreveu a obra, foi constatada uma linha tênue entre o conceito de analisar e o de descrever.

De acordo com o Mini Dicionário Aurélio (1977) o termo "análise" refere-se ao exame de cada parte de um todo para conhecer-lhe a natureza, as funções e o termo descrever refere-se a descrição de algo, a narrativa, o contar minuciosamente.

Nas respostas deste grupo foi amplamente aplicada a descrição, o minucioso dos detalhes da obra que, de início chamaram a atenção dos respondentes, tais como: as pessoas, o céu, os mastros da jangada, corpos estirados e seminus.

As respostas têm como referência somente a noção da imagem, portanto, o uso da informação vinculou-se essencialmente à representação visual. O grupo observou apenas a obra física (obra tangível), em sua forma (quadro 1, pág. 09 deste estudo) motivo pelo qual foi utilizada a descrição. O receptor não percebeu a obra de arte como um sistema simbólico e a informação artística seguiram pelo caminho da representação visual, como seguem nos exemplos abaixo:

“"A obra" A Jangada da Medusa" demonstra várias pessoas em uma jangada."

“Jangada no mar com várias pessoas, olhando, apontando em direção ao céu. Pessoas com aparência de escravos, servos.”

“A obra retrata uma jangada com homens nus e seminus que parecem estar em estado de sofrimento, enquanto outros parecem se impressionar com algo que estão observando.”

"A obra retrata pessoas à bordo de uma jangada, em um dia nublado, pessoas cansadas, umas mais, outras menos."

“Analisando a imagem temos uma jangada com mastros grandes com um pano branco na ponta e muitas pessoas deitadas, uma em cima da outra e outras à beira da jangada tentando avistar 
algo ou resolver algo. Aparentemente, todas as pessoas estão desesperadas por motivos desconhecidos e um céu totalmente acinzentado, trazendo uma grande tempestade."

“A obra mostra como título uma jangada onde há muitas pessoas, umas por cima das outras, como se fossem prisioneiros, escravos, doentes e morrendo, procurando chegar a algum lugar para que possam ser ajudados."

"A Jangada da Medusa", uma obra de grande importância, pois se não fosse tão importante não estaria no Louvre, em Paris. Valiosa, provavelmente cobiçada. Na pintura se vê uma jangada que parece naufragada. Corpos estirados, parados, como se fossem pedras, mas ao mesmo tempo expressão de movimento".

O terceiro e último grupo buscou referências cognitivas para servir de alicerce para a análise da obra, identificando e percebendo a dualidade entre o desespero e a esperança que o autor buscou apresentar.

A percepção nasce do cruzamento da obra estética e seu receptor e perceber não é um fenômeno instantâneo pois o processamento da informação artística tem íntima ligação com o tempo, mesmo que este tempo seja limitado, como aconteceu no processo de pesquisa. O ser humano explora uma imagem por fixações sucessivas, que se revertem às partes da imagem mais providas de informação, como os seguem os exemplos abaixo:

"A arte dependendo do desenho nos emocionam muito e foi isso que me aconteceu: emocionei-me pois, com tanto sofrimento pessoas ainda têm esperança, assim como eu, para um mundo melhor".

““ A Jangada da Medusa", uma obra marcante. A angústia representada na obra rompe a tela e chega até o espectador, que talvez pense: "quero sair logo daqui". Talvez como as pessoas representadas". 
"Pode-se concluir que nessa obra se observa desespero e sofrimento e até pode-se dizer esperança para os que aparentam ser fortes e que estão vivos e com os punhos levantados parecem pedir ajudar aos céus".

“Ao pôr-do-sol e em plena agonia, eles lutavam pela sobrevivência que parecia tão distante diante do caos que habitava sobre aquela pequena jangada, a jangada da morte, mas que se transformava na jangada da vida de alguns pobres sobreviventes que só viam esperança naquele resto de pôr-do-sol”.

“A jangada destruída e as nuvens escuras. As que gritavam pedindo socorro ainda tinham esperanças de sobreviver em meio aos corpos caídos".

"Uma obra que expressa o sofrimento, uma jangada com pessoas precisando de ajuda. Longe de todos, sozinhos, muitos não resistiram e os que restaram acenam na esperança de ajuda".

“Corpos quase empilhados olhando numa mesma direção. Seria o arco-íris? Esperança? Prefiro acreditar que era esperança e que, esses homens e mulheres tenham sempre o que falta para muitos: esperança. Apesar de que esse tom de cores me passa um ar cansado, melancólico, quase que contido".

"As cores frias na obra passam uma sensação de aflição a quem a observa e tenta analisala".

“A obra é composta por tons de marrom, o que deixa a obra com uma aparência escura, dando um clima de tensão e suspense. O medo e o desespero nas pessoas mostram que eles estão querendo fugir de alguma coisa, algo assustador. O clima criado na obra também dar-se a entender essa idéia".

A cognição é uma "sobreestrutura" abordável através de alguns tópicos básicos e essenciais: a percepção, a memória, modelos conexionistas, representação mental, a imagem mental, a resolução de problemas, o raciocínio, o raciocínio dedutivo, o indutivo, a cognição social e o desenvolvimento cognitivo. 
Uma obra estética, analisada por um grupo de pessoas que desconheça sua técnica, sua representatividade provoca um aumento de saber/ de conhecimento/ de informação, mas a assimilação geradora de novos conteúdos/ de novas obras sobre a mesma temática, deve reunir várias condições endógenas e exógenas facilitadoras dessa dinâmica. Estabelece-se, assim, uma diferenciação orgânico-funcional entre os "produtos" da cognição humana - os textos, as imagens, os desenhos etc., isto é, o conhecimento ou a informação manifesta - e os processos cognitivos (os processos de cognição) propriamente ditos.

Neste grupo, os respondentes observaram a obra estética e buscaram referências da imagem em seu estoque de informação mental, ou ainda relacionaram a imagem da obra com um objeto concreto, pertencente ao seu dia-a-dia. Neste caso, o autor da obra trouxe para o observador a historicidade que pertence ao objeto que a imagem representa.

\section{Análise percentual dos entrevistados que participaram da atividade e receberam a segunda folha - Grupo C}

Dos $30 \%$ que receberam a segunda folha, foi detectado que:

- $67 \%$ dos pesquisados não utilizaram as informações da segunda folha em suas análises

- $33 \%$ dos pesquisados utilizaram as informações contidas na segunda folha. 
TABELA 3

Percentual de participantes da atividade que receberam a segunda folha utilizando-a ou não em sua resposta (múltiplas respostas).

\begin{tabular}{c|c|c}
\hline $\begin{array}{c}\text { Número de } \\
\text { respondentes }\end{array}$ & Característica & $\%$ \\
\hline \multirow{2}{*}{24} & $\begin{array}{l}\text { Mesmo recebendo a segunda folha, } o \\
\text { respondente não alterou sua primeira } \\
\text { análise. Não se utilizou da informação }\end{array}$ & 67 \\
\hline \multirow{2}{*}{12} & $\begin{array}{c}\text { Efetivamente o respondente utilizou-se da } \\
\text { segunda folha ou para alterar sua análise ou }\end{array}$ & 33 \\
& para completa-la & \\
\hline
\end{tabular}

O principal questionamento na análise deste grupo está relacionado à necessidade da informação. A princípio, pode-se esperar que o receptor, neste caso, o respondente, tendo acesso à informação contida na segunda folha, tenha uma atitude de consumo imediato da mesma. Porém, $67 \%$ dos respondentes que receberam a segunda folha, não a utilizaram para alterar a primeira análise. Percebe-se que não existiu uma motivação, isto é, um impulso, talvez por falta de uma mediação atuante.

Mesmo com a informação contida na segunda folha, o valor de uso, que procura determinar a utilidade da informação para o respondente, superou o valor semiótico, que é a medida da competência individual do respondente em decodificar a estrutura dos signos que constam na obra, auxiliados pela informação constante da segunda folha, para realizar o entendimento necessário ao consumo da informação, como veremos nos exemplos abaixo:

"Fiz a análise antes de receber a segunda folha. Apesar de ter entendido melhor a pintura após a leitura, não modifiquei minha análise por não ter percebido os detalhes sozinha”.

“Apesar das técnicas usadas que o pintor utilizou fica uma dúvida em saber o que na verdade ele queria passar". 
"Referente à técnica utilizada seguida dos detalhes sutis, entendo que somente um apreciador de arte mais atento e afinado poderia notar".

Porém, além das respostas justificando a não utilização da informação constante na segunda folha, foram detectadas, também neste grupo, respostas contendo descrições e novas interpretações para a obra, como seguem nos exemplos abaixo:

"Quando recebi a segunda folha, analisei que o pintor quis passar através da obra que por trás da derrota, sempre há esperança".

"O nome da obra é intrigante, porque Medusa? Talvez eles tenham encontrado Medusa (a mulher com cobras no lugar de cabelos e que transforma em pedra que a olhasse) e conseguindo escapar dela, ou ainda, a jangada pode ser uma mulher chamada Medusa”.

"Em relação aos dias de hoje, posso dizer que a "Jangada da Medusa" representa para mim a disputa, seja ela por um emprego, seja por uma oportunidade, seja para alcançar um sonho. Mas, depois que recebi a segunda folha e li o texto, pude compreender melhor a obra e o sentimento, o objetivo que o pintor queria transmitir".

Neste caso, mesmo alegando ter compreendido melhor a obra através da segunda folha, o respondente não alterou sua resposta.

"Não tive a visão do navio, nem dos triângulos e nem do que poderia representar as nuvens de tempestade e ondas escuras e nem o brilho do horizonte. Após ler a análise da segunda folha, consegui enxergar todos os elementos citados".

Neste caso, também, mesmo alegando ter compreendido melhor a obra através da segunda folha, manteve sua avaliação inicial.

"Com a segunda folha consegui interpretar melhor esta obra e mostrar através desta folha minhas emoções" (Mesmo caso das duas interpretações anteriores). 
"Ao receber a folha com algumas dicas ficou mais claro o entendimento, pois não tinha conseguido notar a esperança" (Idem).

“A obra passa o sofrimento, ou a miséria ou até mesmo uma população indignada com seus governantes, com seu modo de vida difícil”.

"Eu entendo que essa jangada está naufragando, por causa de uma tempestade. Ela está super lotada e isso ajuda o naufrágio".

"Nessa obra há algumas pessoas mortas aparentemente e algumas aflitas sobre uma jangada. Onde o pintor retrata as vítimas de um naufrágio que aconteceu por causa do mau tempo. Ainda há pessoas com esperança de serem resgatadas e outras que se entregaram à morte”.

Assim como no Grupo B, referenciais cognitos e imaginários foram utilizados para a solução do problema proposto pela atividade.

Em relação ao grupo dos $33 \%$ dos respondentes que utilizaram as informações contidas na segunda folha, houve uma preocupação em alterar a primeira análise feita - 10 minutos antes - e inserir conceitos presentes na segunda folha, como seguem nos exemplos abaixo:

"O dourado predominante, além da idéia de preciosismo, implica na observação do reflexo do pôr-do-sol. Ao fundo, o céu obscuro, nebuloso e predominantemente amarelo. O escurecimento, o sombreado praticamente inevitáveis ao aglomerado de corpos. E, por fim, um provável sinal de esperança do rosado da vela da jangada".

“A disposição das figuras demonstra pavor e esperança".

“Composição: o pintor divide a cena em dois triângulos superpostos, um lado do triângulo mostra pessoas mortas e moribundas e outro renasce a esperança; e isso faz com que dê equilíbrio na obra. As cores e contrastes, como por exemplo, da nuvem de tempestade e de ondas encrespadas, escuras para criar um clima ameaçador". 
"O desespero e dor são fortemente demonstrados e a esperança com a luz que clareia o caminho, demonstram os contrastes nas cores entre o claro e o escuro, trazendo assim equilíbrio na imagem".

"O autor retratou um grupo de pessoas à beira de um naufrágio, a luta pela sobrevivência. Organiza as pessoas em forma de triângulo, um à esquerda, outro à direita, com isso o autor focaliza o olhar do espectador ao ápice da obra. $\mathrm{O}$ autor para criar uma sensação de desespero desenha nuvens negras, com um brilho no horizonte para retratar a esperança dos náufragos".

“Aprofundando-se mais na obra se percebe que o autor colocou dois sentimentos na obra: o das pessoas desesperadas e o das pessoas que ainda têm esperança quando vêem um navio em sua direção".

"O que se percebe no quadro de Géricault é como o autor conseguiu unir quatro fatores imprescindíveis num quadro de maneira perfeita usando: cor, composição, clima e luz, o pintor consegue transmitir as sensações que os tripulantes da "Jangada da Medusa" tinham naquele exato momento. Um aspecto interessante é a divisão do quadro em dois triângulos, um dos mortos e o outro dos esperançosos".

"Em minha opinião, a obra "A Jangada da Medusa", composta por cenas fortes de morte, desespero e esperança, se destaca pelo movimento criado pelas figuras caídas e também pelas figuras que acenam por socorro".

“As cores, a pessoa abanando à chegada repentina da esperança, o braço de uma pessoa cortando o mastro da jangada, os movimentos agonizantes das pessoas deitadas, os dois triângulos que não chegam a se juntar e o horizonte logo à frente."

“A pintura apresenta desespero e esperança. Géricault conseguiu misturar entre cor, composição, clima e luz perfeitamente". 
"A separação dos planos nesse quadro se dá por triângulos, um com a "dor" e o outro com a "luta". Os elementos naturais da cena, como as ondas e as nuvens, completam esta cena, trazendo a unidade à obra".

"Conheci conhecer as técnicas de iluminação, pintura e isso nos causa uma realidade da foto. Pelas disposições do quadro, cria realismo."

Nesse pequeno grupo de respondentes que utilizaram da informação constante na segunda folha, pode-se assinalar a presença de termos apresentados por Strickland, construindo um texto mais técnico, apesar do grupo não ser especialista em arte.

A utilização desses termos propicia certa credibilidade, maturidade e profissionalismo ao texto. Logo abaixo algum dos termos mais usados pelos respondentes, que não constam nas respostas dos outros grupos:

- Triângulos

- Movimento

- Cor

- Contraste claro/ escuro

- Clima

\section{CONSIDERAÇÕES FINAIS}

Através da análise dos resultados do estudo empírico, pode-se concluir que por mais que a arte possa ser divulgada a um grande público, fica sempre uma desconfiança no que se refere ao uso da informação artística adquirida.

Grandes sistemas de informação sobre a arte utilizam-se de estratégias oferecidas pela mídia para efetivamente facilitar a divulgação e o acesso à determinada mostra, acervo ou exposição, com o intuito de motivar o público a participar. Mas o fato de ter grande público não autoriza afirmar que o evento atingiu seu objetivo com sucesso - relação forma e função. 
Se a produção de conhecimento requer um sujeito (público), uma linguagem (linguagem artística) que atinja este público e um objeto (a obra), a informação facilita o acesso ao conhecimento da arte, porém pode, também, assumir diversas faces, como resultou na pesquisa experimental: a informação como imaginação, como cognição, como descrição, resultados obtidos pelo subgrupo B, encurtando a distância do público em relação à obra.

Antes de ter acesso à informação artística, é necessário distinguir e deixar claro qual o seu objetivo, seu uso e as necessidades que deverão ser sanadas em relação ao seu público. Na ambiência da informação, é a oferta que determina a demanda - a informação tem que ser reconhecida pelo receptor, fato resultante da pesquisa experimental do subgrupo C, em que dos $30 \%$ dos respondentes que receberam a segunda folha, apenas 33\% utilizaram a informação em sua análise. Para os $67 \%$ restantes, a informação não foi reconhecida e seu uso foi descartado.

Fica claro que facilitar o acesso não basta, pois a linguagem artística necessita de um “incremento" para ser reconhecida e quem sabe aumentar o percentual de usuários. É preciso determinar a sua função diante do público e como será apresentada, através da mediação. E a mediação humana é a mais eficaz, desde que esta mediação passe por uma formação anterior, visando indicar e direcionar o valor da informação para este público.

Em relação à pesquisa empírica, o fato de se ter acesso à informação sobre a obra de Géricault não resultou o seu uso nas análises. Não houve o reconhecimento da informação por parte do público, embora ela tenha sido disponibilizada. Permanece, portanto, a dúvida de que uma linguagem mais simples como veículo da informação poderia, efetivamente, resultar em sua maior utilização.

Com o objetivo de reconhecer este "algo a mais" nas obras artísticas, o público ou recorre à análise física da obra ou desenvolve associações simbólicas, como foram apresentadas nas respostas do Grupo B do estudo empírico. Afinal, o conhecimento do mundo é uma construção individual e o receptor é quem deverá reconhecer a informação que necessita e compará-la aos estoques mentais do observador. 
Outra conclusão que se obtém é que a informação é uma das formas de acesso à arte. Encurta a distância entre a arte e o público, através de uma mediação eficiente, devendo ser reconhecida e compreendida por meio de uma linguagem acessível e deve estar de acordo com as necessidades do público. Cria uma relação entre o processo artístico e a interpretação do homem e os resultados do estudo empírico comprovam esta relação. É o processo de transferência de conhecimento mediante processos de socialização, educação e aprendizado.

A mediação eficaz prepara o público para o processo de transferência da informação e auxilia no reconhecimento desse tipo de informação. Não basta ter acesso físico à informação, é necessário ter o acesso intelectual. Com isso a recepção reafirma-se como lugar da produção, como foi detectado nos resultados do estudo empírico com os subgrupos B e C. Mesmo diante da informação ou não, todos os respondentes colaboraram com a produção da informação artística, através de suas respostas. A obra de Géricault, utilizada na pesquisa empírica, obteve vários significados, ou como função ou como forma.

Quando se parte do princípio de analisar a arte no contexto da Ciência da Informação, tornar-se evidente a compreensão de que a arte é seletiva, pois depende da informação a ser disseminada, como já foi comentado, e do público que a está recebendo. Este público precisa ser motivado, preparado e incentivado a fazer da arte uma necessidade básica e, finalmente saciar esta necessidade através da análise informacional da obra estética (função). E esta preparação deve ser contínua e não momentânea, e sim, no decorrer da vida das pessoas, desde criança até a fase adulta, já que arte deveria ser uma necessidade básica, que auxilia a compreensão do mundo atual em que vivemos.

A preparação mais indicada deve ocorrer na família e na educação formal adequada (com autonomia de análise) pela escola, fato este que não acontece com freqüência, principalmente em nosso país, onde se reconhecem ainda apenas as necessidades básicas : alimento, vestuário e habitação.

A arte também depende da cognição, das referências pessoais , do "museu" interior para ser decodificada e interpretada e entendida. É claro que se o público fosse preparado para receber este tipo de informação, a transferência de conhecimento se tornaria mais eficiente. Depende, 
efetivamente, do valor semiótico da obra. Enfim, a obra só tem valor quando é reconhecida por seu público.

A Ciência da Informação oferece subsídios para a preparação e formação do público para a arte, utilizando-se da tecnologia e de estratégias de mídia e ainda oferece suporte para que os sistemas de informação democratizem seus acervos. A interatividade que alguns sistemas de informação estão começando a adotar pode ser considerada uma das estratégias de aproximação da informação com o público, que tem acesso ao conhecimento de forma diferenciada.

Em relação à produção de informação por esses sistemas, como os museus, centros e espaços culturais, museus virtuais e etc, os estoques de informação são grandes, dependendo da necessidade da demanda. A arte pode ser encarada como uma mercadoria de valor, atuando em um mercado competitivo, também. Os gestores da informação sobre a arte precisam aumentar e disponibilizar os acervos periodicamente para atender a demanda.

A arte como necessidade básica ou a arte como uma necessidade de auto-realização? Seja qual for a resposta a esta pergunta, a arte busca atender a um público exigente e bastante específico, e através do estudo da arte no contexto da Ciência da Informação, a arte pode ser uma informação valiosa e que depende de estratégias específicas para ser compreendida pelo seu público.

\section{REFERÊNCIAS}

ARARIPE, F. M. A. Do patrimônio cultural e seus significados. Revista Transinformação, v.16, n.2, p.111-122, 2004.

BAUMGART, F. Breve história da arte. 2. ed. São Paulo, SP: Martins Fontes, 1999.

BOSI, A. Reflexões sobre a arte. São Paulo, SP: Ática, 1985.

BUSH, V. As we may think. Atlantic Monthly, v.176, n.1, p. 101- 108, 1945.

CANCLINI, N. G. A socialização da arte. São Paulo, SP: Cultrix, 1984.

Culturas híbridas: estratégias para entrar e sair da modernidade. São Paulo, SP: Ed.

USP, 2006. 
FERREIRA, A. B. H. Mini dicionário. Rio de Janeiro, RJ: Nova Fronteira, 1977.

JESUÍNO, J. C. Processos cognitivos. In: RODRIGUES, Georgete Medleg; LOPES, Ilza Leite. Organização e representação do conhecimento na perspectiva da Ciência da Informação estudos avançados em Ciência da Informação. Brasilia : Thesaurus Editora, 2001. v.2.

KOBASHI, N. Y. ; TÁLAMO, M. F. G.M. Informação: fenômeno e objeto de estudo da sociedade contemporânea. Revista Transinformação, v.15, n.3, p.7-21, 2003.

LAKATOS, E. M.; MARCONI , M. A. Técnicas de pesquisa: planejamento e execução de pesquisas, amostragens e técnicas de pesquisas, eleboração, análise e interpretação de dados. $5^{\mathrm{a}}$ ed. São Paulo, SP: Atlas, 2002

LE COADIC, Y.-F. A Ciência da Informação. Brasília: Briquet de Lemos, 2004.

OLIVEIRA, V. P. Uma informação tácita. Datagramazero, v.6, n.3, jun/05. Disponível em: (www.datagramazero.com.br) Acesso: 26 de maio de 2005.

ROBREDO, J. Informação, conhecimento e ciência da informação: da ciência da informação revisitada aos sistemas humanos de informação. Brasília: Thesaurus; SSRR, 2003.

SANTAELLA, L.; NÖTH, W. Cognição, semiótica, mídia. São Paulo Iluminuras, 2001.

SERACEVIC,T. Interdisciplinarity nature of information science, Brasília, v.24, n.1. p. 36-41, 1995.

SILVA, A. M. Conhecimento/Informação - sinonímia e/ou diferenciação. In: RODRIGUES, G. M.; LOPES, I. L. Organização e representação do conhecimento na perspectiva da Ciência da Informação - Estudos avançados em Ciência da Informação. Brasília : Thesaurus Editora, 2003. v. 2

STRICKLAND , C. Arte comentada: da pré-história ao pós-moderno. Rio de Janeiro: Ediouro, 2003.

TÁLAMO, M. F. G.M. A pesquisa: recepção da informação e produção do conhecimento. Revista DataGramaZero, v.5, n.2, abr/04. Disponível em www.datagramazero.com.br. Acesso em 26 de maio de 2005.

\section{SITE}

Biografia Theodore Géricault - Disponível em www.dec.ufcg.edu.br/biografias/JeanLATG.html Acesso em 25 de março de 2007. 